Thijs Porck \& Jodie Mann, "How Cnut became Canute (and how Harthacnut became Airdeconut)", NOWELE: North-Western European Language Evolution 67 (2014), 237-243

This is the post-print version, with page numbers of publisher's version added between angle brackets to facilitate referencing.

$<237>$

\title{
How Cnut became Canute (and how Harthacnut became Airdeconut)
}

\section{Abstract}

This article discusses the development of the spelling for the name of Cnut the Great, Viking king of England from 1016 to 1035, from <Cnut $>$ to $<$ Canute $>$. The origin of this disyllabic spelling is uncertain and has been attributed to taboo deflection, the simplification of the consonant cluster $/ \mathrm{kn} /$ in English and even a pope's inability to pronounce the name Cnut. A survey of documents contemporary to Cnut the Great and later chronicles, however, suggests that the disyllabic spelling is found first in sources of Norman origin. As such, the disyllabic spelling <Canute $>$ should be considered a romanisation. This conclusion has important implications for a recently found, early tenth-century coin, bearing the inscription "AIRDECONUT".

In September 2011, a large collection of silver jewelry and coins dating from about 900 AD was discovered in Silverdale, Lancashire, England. From among its items, a coin bearing the inscription "AIRDECONUT" was hailed as one of the most important finds (see Figure 1). Airdeconut was assumed 
to be "the Anglo-Saxon coin maker's struggle to get to grips with the Viking name Harthacnut" and, hence, the coin was regarded as evidence for a hitherto unknown Viking king in Northern England around the year 900 (Kennedy 2011; Richardson 2011). This interpretation has its appeal, but, given that the Airdeconut coin was found among coins of Frankish, Islamic and Viking origins, how can we be certain that the spelling <Airdeconut> for $<$ Harthacnut $>$ is Anglo-Saxon? The present article concerns the spelling of another Viking king's name, whose presence in England, by contrast, is well attested in various sources: Cnut the Great, Viking king of England from 1016 to 1035 . The spelling of Cnut's name underwent a change similar to the one proposed for the Airdeconut coin - from $<$ Cnut $>$ to $<$ Canute $>-$ and a discussion of this change has important implications for the proposed origins of the Airdeconut coin, as will be discussed in the final paragraph. While it is a well-known fact that Cnut the Great is "known in English as Canute” (Hanks, Hardcastle \& Hodges 2006: s.v. 'Knut'), the origin of the disyllabic spelling <Canute $>$ is uncertain. According to Freeman, the Latin form <Canutus $>$ was introduced by the early twelfthcentury Pope Paschal II, because he could not pronounce $<$ Cnut $>$ (Freeman 1867-1876: 442, n. 1). Later scholars have argued that $<$ Canute $>$ is typically English, possibly introduced 


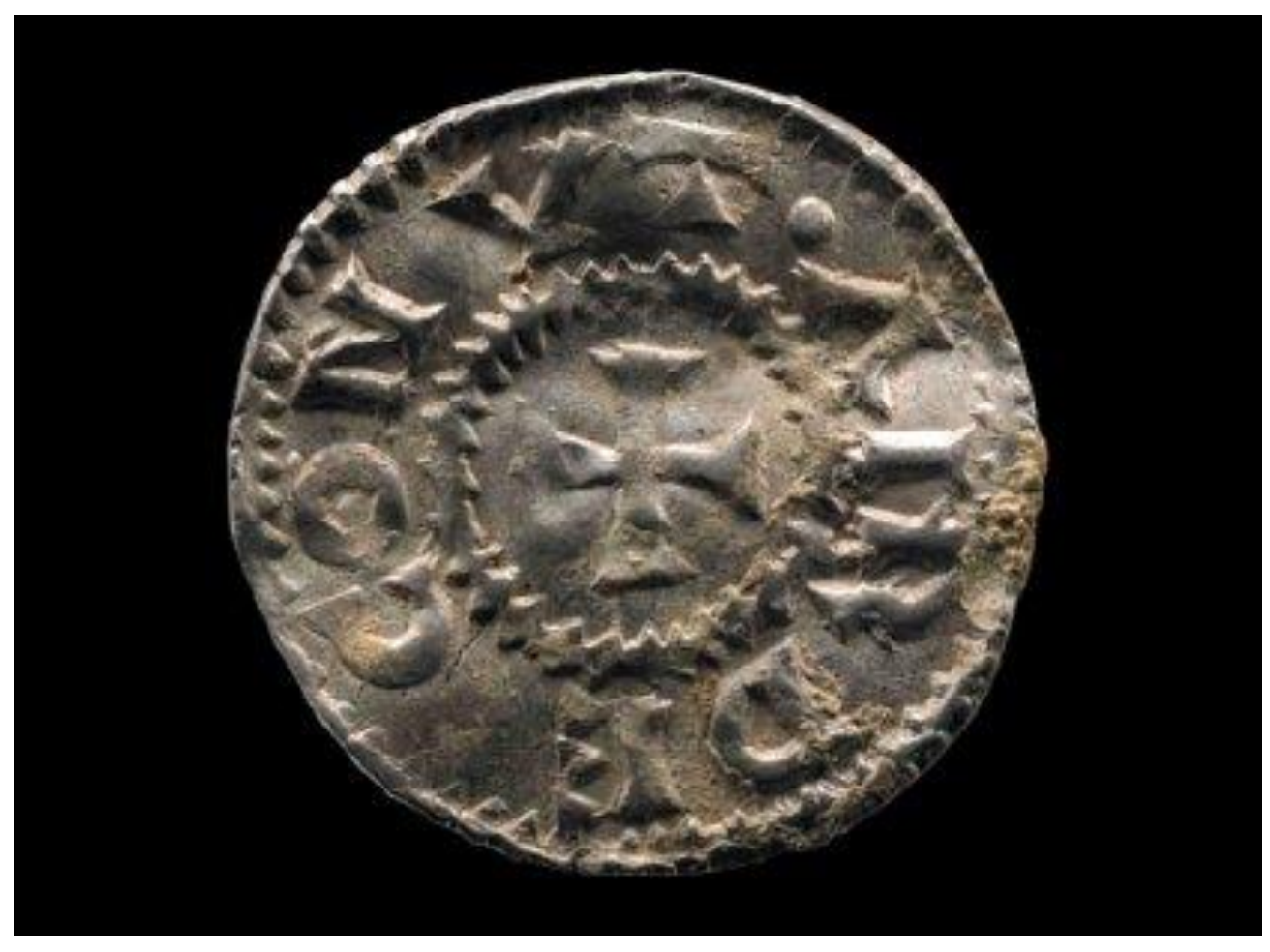

\section{Figure 1. Coin with inscription "AIRDECONUT", attributed to a hitherto unknown Viking king of England.}

to retain the proper pronunciation of the name after the consonant cluster /kn/ was simplified to /n/ in English. ${ }^{1}$ A third hypothesis is based on the principle of taboo deflection: Allan \& Burridge (2006: 45) suggest that the spelling variant <Canute> originated to avoid confusion with vulgar <cunt>

However, the three hypotheses mentioned above are all

\footnotetext{
${ }^{1}$ Von S. Kynell (2000: 18) notes “In Danish, Knüd is difficult for Englishmen to pronounce, and it became variously Cnut in the chronicles, Canute in most American histories, Canute or Cnut in Chambers, and Knut in Jespersen, himself a Dane". See also: "It is spelled Cnut but it is pronounced Canute" (Hanafin, Gearey \& Brooker 2004: 136).
} 
unsatisfactory as disyllabic spellings for the Viking king's name are found well before the proposed triggers. The first recorded disyllabic spelling, $<$ Chanut $>$, is contemporary to the Viking king and is found in two of his own charters (Sawyer 1968: nos. 949,

\section{<239>}

982). As such, it is recorded some seventy years before Paschal II was inaugurated, and occurs at least six centuries before the simplification of $/ \mathrm{kn} /$ to $/ \mathrm{n} /$ in English, a process which probably took place over the course of the seventeenth and eighteenth centuries (Kökeritz 1945: 77-86). The disyllabic form also pre-dates the first recorded instance of the word cunt, which, according to the $O E D$, is found in 1230 , in the street name “Gropecuntelane". On its own, the word cunt occurs first in 1325, i.e. three centuries after we find a disyllabic spelling for Cnut's name. ${ }^{2}$ Neither Paschal II's speech impediment, nor the simplification of $/ \mathrm{kn} /$ to $/ \mathrm{n} /$, nor the confusion with <cunt $>$, therefore, can account for the change from $<$ Cnut $>$ to $\langle$ Canute $>$.

In order to come to a better understanding of how the disyllabic spelling for Cnut's name arose, we have collected the forms of his name from contemporary documents as well as from a selection of twenty later chronicles (see table 1). ${ }^{3}$ Based on our evidence, we would like to propose

\footnotetext{
${ }^{2}$ It seems unlikely that the Old English word for genitalia, (ge-)cynd, would have had any influence on the spelling.

${ }^{3}$ As we wanted to make sure that the chronicles contained Cnut the Great's name, we have selected the chronicles on the basis of them being used in the
} 
that the reason for the change in spelling lies in the language and origin of

the documents in which we find the first disyllabic variants of Cnut's name.

$<240>$

\begin{tabular}{|l|l|}
\hline Author, Chronicle & $\begin{array}{l}\text { Attested } \\
\text { form(s) }\end{array}$ \\
\hline Adémar of Chabannes, Historia Francorum (1025-1029) & Canotus \\
\hline Rodulf Glaber, Historiarum Libri Quinque (1030-1046) & Canuc \\
\hline $\begin{array}{l}\text { Anonymous, Gesta Cnutonis regis } \text { [Encomium Emmae reginae] } \\
(1042-1052)\end{array}$ & Cnutus \\
\hline $\begin{array}{l}\text { William of Jumièges, Gesta Normannorum Ducum (1050- } \\
1067)\end{array}$ & Chunutus \\
\hline Anonymous, Vita AEdwardi regis (c. 1067) & Cnutus \\
\hline William of Poitiers, Gesta Guillelmi (c. 1071) & Chunutus \\
\hline $\begin{array}{l}\text { Herman the Archdeacon, De miraculis sancti Edmundi (c. } \\
1095)\end{array}$ & Chnutus \\
\hline $\begin{array}{l}\text { Symeon of Durham, Historia Dunelmensis ecclesie (1104- } \\
1109)\end{array}$ & Cnutus \\
\hline Orderic Vitalis, Historia ecclesiastica (1114-1140) & Cunutus \\
\hline John of Worcester, Chronicon chronicarum (1122-1141) & Canutus \\
\hline $\begin{array}{l}\text { William of Malmesbury, De Antiquitate Glastoniensis } \\
\text { Ecclesiae (early-12th century) }\end{array}$ & Cnutus \\
\hline $\begin{array}{l}\text { William of Malmesbury, Gesta Pontificum Anglorum (early- } \\
12 \text { th century) }\end{array}$ & Cnutus \\
\hline William of Malmesbury, Gesta Regum Anglorum (1125-1140) & Cnutus \\
\hline Henry of Huntingdon, Historia Anglorum (1129-1154) & Cnutus \\
\hline Geoffrey of Monmouth, Historia regum Brittaniae (1135-1139) & Canutus \\
\hline Geffrei Gaimar, L'Estoire de Engleis (1136-1137) & Kenut/Cnuth \\
\hline Hugh Candidus, Chronicle (12th-century) & Cnutus/Canutus \\
\hline Anonymous, Chronicon Abbatiae Rameseiensis (c. 1170) & Cnutus \\
\hline $\begin{array}{l}\text { Anonymous, Historia ecclesie Abbendonensis (later 12th } \\
\text { century) }\end{array}$ & Cnutus \\
\hline Anonymous, Waltham Chronicle (late-12th century) & Cnutus \\
\hline $\begin{array}{l}\text { Thomas of Marlborough, Chronicon Abbatiae de Evesham } \\
\text { (1218-1229) }\end{array}$ & Canutus/Cnutus \\
\hline Ranulf Higden, Polychronicon (1327-1352) & Canutus \\
\hline Table 1: Overview of chronicles and attested forms. \\
\end{tabular}

Table 1: Overview of chronicles and attested forms. ${ }^{4}$

In the eleventh century, disyllabic forms of his name occur only in

standard works on Cnut the Great: Lawson (2004) and Bolton (2009). For all the cited texts, we have made use of the standard editions.

${ }^{4}$ We have listed forms such as "Cnuti" and "Cnuto" as <Cnutus> and forms such as "Canuti" and "Canuto" as $<$ Canutus $>$. Titles and dates of the chronicles are from Dumphy (2010). 
Latin texts from Normandy and France. Documents written in English, such as the Anglo-Saxon Chronicle, Cnut's law codes and letters, give monosyllabic forms. Such forms without an epenthetic vowel are also found in the Encomium Emma reginae and the Vita Adwardi regis, both composed by monks from Flanders, and in the majority of Cnut's own Latin charters. As mentioned above, however, two of these Latin charters read <Chanut $>$ and these were both written at Fécamp Abbey, Normandy. Similarly, all early disyllabic spelling variants listed in table 1 are found only in Latin texts, written by French or Norman authors such as Adémar of Chabannes, Rodulf Glaber, William of Jumièges and William of Poitiers. A French or Norman origin for the disyllabic spelling may be related to difficulties in pronunciation and makes phonological sense: Romance languages, such as (Anglo-) Norman,

$<241>$

Old French and Latin, disallow onsets such as $/ \mathrm{kn} /$ and $/ \mathrm{gn} /$ and one way to remedy these onsets is to insert an epenthetic vowel between the velar and the nasal consonants (Lincoln Canfield \& Cary Davies 1975; Minkova 2003: 337).

As shown in table 1, Latin chroniclers in the twelfth century tended to use two distinct forms: <Cnutus> and <Canutus>. In three chronicles, both variants were found. Geffrei Gaimar's L'Estoire des Engleis (11361137), written in Anglo-Norman, for example, reads "Kenut fut bon rei riche e poant / Sa realted esteit mult grant / Danemarche ot e Englettere /... / Cum 
Cnuth regnout meillurment / .../ Dunc fud Kenut de treis regnes sire” (Bell 1960: 11. 4676-4689). The variant <Cnuth>, however, is probably a scribal error, as Gaimar himself intended a disyllabic pronunciation of Cnut's name: his $L$ 'Estoire is written in octosyllabic lines and the line with the variant $<$ Cnuth $>$ numbers only seven syllables. The variation in Hugh Candidus's chronicle can be explained by the fact that the form 'Canutus' is only found in a chronological summary, which was added by a later annotator (Mellows 1949: 49, 136-137). Finally, the variation in Thomas of Marlborough's Chronicon Abbatiae de Evesham may simply indicate that by the thirteenth century both spelling variants were used interchangeably (Macray 1863: 36, $83)$.

The evidence presented above suggests that the disyllabic forms ultimately derive from French or Norman authors writing in Latin. Eventually, English chroniclers writing in Latin adopted this practice and when these Latin chronicles were finally translated into English, <Cnut $>$ became $<$ Canute $>$ in English. The latter development is illustrated by the first occurrence of a disyllabic form in a text in English. In his translation of Ranulf Higden's Polychronicon (1387), John of Trevisa wrote “Afterward, aboute Lenten, pe kyng comynge hastely drof Canut out of Lyndeseie" and probably based the spelling <Canut> on Higden's Latin original: "Postmodum rex circa quadrages imam festine adveniens, Canutum de Lindeseya profugavit" (Lumby 1865-1886: VII, 98-99). 
In conclusion, while the traditional hypotheses may explain why $<$ Canute $>$ remains the preferred spelling of Cnut's name - negating as it does the possibility of him being called King Nut the Great ${ }^{5}$ or King Cunt the Great ${ }^{6}$ - they cannot

\section{$<242>$}

be seen as explanations for the origin of this spelling variety. Rather than an anglicisation or taboo deflection, the spelling <Canute> should be regarded as a romanisation of $\langle$ Cnut $>$.

Let us, finally, return to the Silverdale Hoard coin bearing the inscription "AIRDECONUT". The spelling of the name < Harthacnut $>$ as $<$ Airdeconut $>$ presents an interesting parallel to the change from $<$ Cnut $>$ to $<$ Canute $>$. Based on our evidence, the breaking up of the $/ \mathrm{kn} /$ cluster in $<$ Airdeconut> indicates a French or Norman origin. A second phonological argument is the loss of the initial $/ \mathrm{h} /$, which is another typical feature of Old French (Fagyal, Kibbee \& Jenkins 2006: 224). "AIRDECONUT”, therefore, should not be seen as a failed attempt by an Anglo-Saxon to spell the name Harthacnut, but as a reflection of the French or Norman pronunciation of the name. Possibly, Adam of Bremen's Gesta Hammaburgensis ecclesiae pontificum provides a further clue to the identity of the ruler on the

\footnotetext{
${ }^{5}$ According to Bardsley (1996: 592), the surnames Notman, Nutman and Nuttman may be derived from 'the servant of Note (Cnut or Canute)'. We assume that these names would initially have been spelled with intitial $\langle\mathrm{cn}\rangle$ and developed into their present forms later on.

${ }^{6}$ Occasionally, misspellings make it into print. For example, Alexander Rumble's The Reign of Cnut (1994) is referred to as "The Reign of Cunt", in Lee (2003: 393).
} 
Airdeconut coin. Adam records that a certain Harthacnut replaced Sigtrygg as king of Denmark during the tenure of Archbishop Hoger of Bremen (908915). This Harthacnut, Adam of Bremen reports, travelled to Denmark, "veniens a Northmannia" [coming from Normandy] (Pertz 1846: I, 54). ${ }^{7}$ Rather than evidence for an unknown Viking king in England, therefore, the Airdeconut coin from around 900 AD might well be connected to the Viking King Harthacnut who came from Normandy and never ruled in England.

Thijs Porck \& Jodie Mann

Leiden University Centre for Arts in Society

Department of English Language and Culture

Postbus 9515

NL-2300 RA Leiden

m.h.porck@hum.leidenuniv.nl

j.e.v.mann@umail.leidenuniv.nl

$<243>$

References:

Allan, K. \& K. Burridge. 2006. Forbidden Words: Taboo and the Censoring of Language. Cambridge: Cambridge University Press.

\footnotetext{
${ }^{7}$ Here, Harthacnut's name is spelled "Hardegon"; in Pertz (1846: I, 57), he is referred to as "Hardecnudth".
} 
Bardsley, C.W. 1996. A Dictionary of English and Welsh Surnames.

Baltimore: Genealogical Publishing Co., Inc.

Bell, A. (ed.). 1960. L'Estoire des Engleis by Geffrei Gaimar. Oxford:

Oxford University Press.

Bolton, T. 2009. The Empire of Cnut the Great. Conquest and the

Consolidation of Power in Northern Europe in the Early Eleventh

Century. Leiden \& Boston: Brill.

Dumphy, G. (ed.). 2010. Encyclopedia of the Medieval Chronicle. Leiden \& Boston.

Fagyal, Z., D. Kibbee \& F. Jenkins. 2006. French: A Linguistic Introduction. Cambridge: Cambridge University Press.

Freeman, E.A. 1867-1876. The History of the Norman Conquest of England: Its Causes and its Results. Oxford: Clarendon Press.

Hanafin, P., A. Gearey \& J. Brooker. 2004. Law and Literature. Oxford: Wiley-Blackwell.

Hanks, P., K. Hardcastle \& F. Hodges. 2006. A Dictionary of First Names. Oxford: Oxford University Press.

Kennedy, M. 2011. 'Evidence for Unknown Viking King Airdeconut Found in Lancashire'. The Guardian, 14 December 2011. <http://www.guardian.co.uk/science/2011/dec/14/viking-kingairdeconut-treasure-lancashire> [Accessed 26 October 2012].

Kökeritz, H. 1945. 'The Reduction of Initial/kn/ and /gn/ in English'. Language 21.77-86. 
Lawson, M.K. 2004. Cnut. England's Viking King. Stroud: Tempus.

Lee, P. 2003. The Rough Guide to Norway. London: Rough Guides.

Lincoln Canfield, D. \& J. Cary Davies. 1975. An Introduction to Romance

Linguistics. Carbondale: Southern Illinois University Press.

Lumby, J.R. (ed.). 1865-1886. Polychronicon Ranulphi Higden. London: Longman.

Macray, W.D. (ed.). 1863. Chronicon Abbatiae de Evesham. London: Longman..

Mellows, W.T. (ed.). 1949. The Chronicle of Hugh Candidus, a Monk of Peterborough. Oxford: Oxford University Press.

Minkova, D. 2003. Alliteration and Sound Change in Early English. Cambridge: Cambridge University Press.

Pertz, G.H. (ed.). 1846. Adami. Gesta Hammaburgensis Ecclesiae Pontificum. Hannover: Impensis Bibliopolii Hahniani.

Richardson, I. 2011. 'Two Hoards and One Unknown Viking Ruler'. British Museum Blog, 14 December 2011. < http://blog.britishmuseum.org/2011/12/14/two-hoards-and-oneunknown-viking-ruler/> [Accessed 26 October 2012].

Sawyer, P.H. 1968. Anglo-Saxon Charters: An Annotated List and Bibliography. London: Royal Historical Society.

von S. Kynell, K. 2000. Saxon and Medieval Antecedents of the English Common Law. Lewiston: Edwin Mellen Press. 